\title{
Human Resource Accounting (HRA): A Conceptual Study on Human Capital.
}

\author{
Md.Mohiuddin ${ }^{1}$, Meher Nigar Banu ${ }^{2}$ \\ ${ }^{I}$ Associate Professor Department of Management Studies Jagannath University, Dhaka. \\ ${ }^{2}$ Associate Professor Department of Accounting Govt.Titumir College, Dhaka.
}

\begin{abstract}
Human Resource Accounting (HRA) is a new branch of accounting. It is based on the traditional concept that all expenditure of human capital formation is treated as a charge against the revenue of the period as it does not create any physical asset. But now a day this concept has changed and the cost incurred on any asset (as human resources) should be capitalised as it yields benefits measurable in monetary terms. Human Resource Accounting means accounting for people as the organisational resources. It is the measurement of the cost and value of people to organisations. It involves measuring costs incurred by private firms and public sectors to recruit, select, hire, train and develop employees and judge their economic value to the organisation. HRA furnishes cost/value information for making management decisions about acquiring, allocating, developing, and maintaining human resources in order to attain cost-effectiveness.
\end{abstract}

Keywords: Human Resource Accounting (HRA), Human Capital, Intellectual Capital Approach.

\section{Intrduction}

Human resource accounting is an attempt to identify and report investments made in the human resources of an organisation that are not presently accounted for under conventional accounting practice. Basically, it is an information system that tells the management what changes overtime are occurring to the human resources of the business, and of the cost and value of the human factor to the organisation. Human Resource Accounting is the activity of knowing the cost invested for employees towards their recruitment, training them, payment of salaries \& other benefits paid and in return knowing their contribution to organisation towards it's profitability. The American Accounting Association's Committee on Human Resource Accounting has defined Human Resource Accounting as "the process of identifying and measuring data about human resources and communicating this information to interested parties". HRA, thus, not only involves measurement of all the costs/ investments associated with the recruitment, placement, training and development of employees, but also the quantification of the economic value of the people in an organisation.

Human Resource Accounting (HRA) is a new branch of accounting. It is based on the traditional concept that all expenditure of human capital formation is treated as a charge against the revenue of the period as it does not create any physical asset. But now a day this concept has changed and the cost incurred on any asset (as human resources) should be capitalised as it yields benefits measurable in monetary terms. Human Resource Accounting means accounting for people as the organisational resources. It is the measurement of the cost and value of people to organisations. It involves measuring costs incurred by private firms and public sectors to recruit, select, hire, train and develop employees and judge their economic value to the organisation. The system may serve both the internal and external users, providing management (internal users) with relevant data on which to base recruiting, training and other development decisions and supplying investors, lenders and other external users of financial statement with information concerning the investment in and utilisation of human resources in the organisation. Accounting is a man-made art and its principles and procedures have been evolved over a long period to aid business in reporting for the management and public. Of the four factors of production, viz., man, money, material and land, the last three of them are amenable to conventional accounting, but the first one, i.e., the human resource has not been subject to such accounting. Over the last two decades the idea of accounting for human resources is gaining active consideration. Much of the work on accounting for human resources focused primarily on development or validation of HRA concepts. The traditional practice of treating all expenditure on human capital formation as an immediate charge against income is not consistent with the treatment accorded to comparable outlays in physical capital. The American Accounting Association strongly critised the practice of assigning a Zero value to an asset and stated that 'Costs should be capitalised when they are incurred in order to yield future benefits and when such benefits can be measured.' Management of any concern continuously strives hard for obtaining maximum efficiency. In order to measure the effectiveness of any firm the normal method is to examine financial statements. These statements include balance sheets in which physical assets such as cash accounts receivables, inventory and plant are recorded. These statements normally do not mention the productive capacity of the workers or goodwill of the company. HRA is the art of valuing, recording and presenting systematically the work of human resources in the books of accounts of an 
organisation. Thus, it is primarily an information system, which informs the management about the changes that are taking place in the human resource of an organisation.

\section{Objectives Of The Study}

The main objective of this paper is to explore the concept of Human Resource Accounting which focuses on human capital as an asset from the perspective of strategic human resource planning. Specific objectives are:

- $\quad$ To search the definitions, views of Human Resource Accounting (HRA).

- $\quad$ To identify the advantages, benefits of Human Resource Accounting (HRA).

- To know the methods of Human Resource Accounting (HRA).

- To analyse the Intellectual Capital Approach.

- To examine the limitations, criticisms and disadvantages.

\section{Methodology}

This study is descriptive and conceptual in nature. This article is conducted on the basis of secondary data. This paper is aimed at searching the existing literatures on Human Resource Accounting (HRA). The secondary data have been collected from the journals, published books, newspaper articles and the internet sources are also used.

\section{Definition of HRA:}

\section{Views Of Human Resource Accounting (HRA)}

- "Human Resource Accounting is an attempt to identify and report investments made in human resources of an organisation that are presently not accounted for in conventional accounting practice. Basically it is an information system that tells the management what changes over time are occurring to the human resource in the business." -Woodruff

- "A term used to describe a variety of proposals that seek to report and emphasize the importance of human resources - knowledgeable, trained and loyal employees in a company earning process and total assets." -Davidson and Roman L Weel

- "Human resource accounting is the measurement of the cost and value of the people for the organisation." Eric Flamholtz of university of California, Los Angeles

\section{Objectives of HRA:}

It helps in the development of management principles by classifying the financial consequence of various practices. The objective of HRA is not merely the recognition of the value of all resources used by the organisation, but it also includes the management of human resource which will ultimately enhance the quantity and quality of goods and services. The main objectives of HR Accounting system are as follows:

1. To furnish cost value information for making proper and effective management decisions about acquiring, allocating, developing and maintaining human resources in order to achieve cost effective organisational objectives.

2. To monitor effectively the use of human resources by the management.

3. To have an analysis of the human assets i.e. whether such assets are conserved, depleted or appreciated.

4. To aid in the development of management principles and proper decision making for the future by classifying financial consequences of various practices.

5. In all, it facilitates valuation of human resources recording the valuation in the books of account and disclosure of the information in the financial statement.

\section{Advantages of HRA:}

Human Resource Planning anticipates not only the required kind and number of employees but also determines the action plan. The major benefits of HR accounting are:

1. Information for manpower planning: HRA provides useful information about the cost and value of human resources. It shows the strengths and weakness of the human resources. All this information helps the managers in planning and making the right decisions about human resources. Thus, it provides useful information for Manpower Planning and decision making.

2. Information for making personnel policies: HRA provides useful information for making suitable personnel policies about promotion, favorable working environment, job satisfaction of employees, etc.

3. Utilization of human resources: HRA helps the organisation to make the best utilization of human resources.

4. Proper placements: HRA helps the organisation to place the right man in the right post depending on his skills and abilities. 
5. Increases morale and motivation: HRA shows that the organisation cares about the employees and their welfare. This increases their morale and it motivates them to work hard and achieve the objectives of the organisation.

6. Attracts best human resources: Only reputed organisations conduct HRA. So, competent and capable people want to join these organisations. Therefore, it attracts the best employees and managers to the organisation.

7. Designing training and development programs: HRA helps the organisation to design (make) a suitable training and development program for its employees and managers.

8. Valuable information to investors: HRA provides valuable information to present and future investors. They can use this information to select the best company for investing their money.

\section{Limitations of HRA:}

Criticism, disadvantages, and limitations of human resource accounting (HRA) are:-

1. The valuation of human assets is based on the assumption that the employees are going to remain with the organisation for a specified period. However, this assumption is wrong because employee mobility is very high.

2. The human resource accounting may lead to the dehumanization in the organisation. If the valuation is not done correctly or the results of the valuation are not used properly.

3. In the case of financial accounting, there are certain specified accounting standards which every organisation must follow. However, there are no standards for HRA. Each organisation has its own standards for it. So, there are no uniform standards for it. Therefore, the HRA of two organisations cannot be compared.

4. There are no specific and clear cut guidelines for 'cost' and 'value' of human resources of an organisation. The present valuation systems have many limitations.

5. The life of a human being is uncertain. So its value is also uncertain.

\section{HRA Approaches}

\section{Human Capital Approaches}

Approaches to human resource accounting (HRA) were first developed in 1691. The next approach was developed from 1691-1960, and the third phase was post-1960. There are two approaches to HRA. Under the cost approach, also called the "human resource cost accounting method" or model, there is an acquisition cost model and a replacement cost model. Under the value approach, there is a present value of future earnings method, a discounted future wage model, and a competitive bidding model under.Qunin et al,(1996) and Edwards,(1997) has cited the another important 'Intellectual Capital Approach'. Those are focused below:

\section{Cost Approach}

This approach is also called an acquisition cost model. This method measures the organization's investment in employees using the recruiting, acquisition, formal training and familiarization, informal training and informal familiarization, and experience and development. This model suggests that instead of charging the costs to profit and loss statement accounting, it should be capitalized in the balance sheet. The process of giving a status of asset to the expenditure item is called capitalization. In human resource management, it is necessary to amortize the capitalized amount over a period of time. So, here one will take the age of the employee at the time of recruitment and at the time of retirement. Out of these, a few employees may leave the organization before attaining the superannuation. This method is the only method of Human Resource Accounting that is based on sound accounting principals and policies.

\section{Replacement Cost Approach}

This approach measures the cost of replacing an employee. According to Likert (1985) replacement cost includes recruitment, selection, compensation, and training cost (including the income foregone during the training period). The data derived from this method could be useful in deciding whether to dismiss or replace the staff.

\section{Present Value of Future Earnings Approach}

Lev and Schwartz (1971) proposed an economic valuation of employees based on the present value of future earnings, adjusted for the probability of employees' death/separation/retirement. This method helps in determining what an employee's future contribution is worth today.

\section{Value to the Organization Approach}

Hekimian and Jones (1967) proposed that when an organization had several divisions seeking the same employee, the employee should be allocated to the highest bidder and the bid price incorporated into that division's investment base. For example, a value of a professional athlete's service is often determined by how much money a particular team, acting in an open competitive market, is willing to pay him or her. 


\section{Intellectual Capital Approach}

The productivity of most organisations entering the $21^{\text {st }}$ century is highly dependent on the intellectual capabilities of their employees. the software communications, educational and medical sectors, which provide $79 \%$ of all jobs, owe their success to the knowledge of their employees (Quinn et al,1996). For example, the value of Microsoft was greater than that of General Motors, Ford,Boeing, Lockheed Marteen, Deere, Caterpillar, USX, Weyerhauser, Union Pacific, Kodak, Sears, Marriott, Safeway and Kellog B combind(Lermusiaux,2002). Yet the real and only value of Microsoft is the knowledge of its employees. What is intellect and how is it measured?

Intellectual capital can be thought of as intellectual material(Knowledge) that can be formalized, captured and leveraged to produce a higher -valued asset (Stewart,1994). Intellectual capital can be seen as employee brainpower, some of which is described in skills inventories and patient lists. Quinn and his colleagues (1996) described and ranked the importance of this intellectual capital:

- Cognitive knowledge(know what)

- Advanced skills (know how)

- System understanding and trained institution(know why)

- Self-motivated creativity(care why)

Employers pay premiums for smart workers. In the USA, men with postgraduate degrees earn incomes $130 \%$ higher than men who never finished high school (Qunin et al,1996). The pay gap between men with these different levels of education has doubled since 1980. Intellectual assets have characteristics highly distinct from other assets. First, intellectual assets grow with use. Anyone who has gone back to school or completed a training course realizes that the learning of new knowledge and its application, lead to even greater knowledge and a motivation to acquire more. Intellectual capital can be shared and cannot be depleted. Sharing it results in increased feedback, acquisition of new knowledge and modifications and adjustments to current knowledge.

\section{Issues in Measuring Intellectual Capital}

Expert in the nascent field estimate that the intellectual assets of an organisation are worth three to four times the tangible book value. A common approach is to claim that the intellectual capital of a firm is equal to the difference between a firm's capitalized stock value and its book value. It is still very difficult to put a monetary value on the brain resources of employees. The Canadian Imperial Bank of Commerce (CIBC) tries to do so by counting employee skills( e.g., the ability to manage a portfolio clients), which can be used to build a competency inventory. But as skill change, the dynamics of measuring them become difficult. Furthermore, most of this asset is left idle, observers and employees alike guess that only $20 \%$ of the knowledge available in their companies is used(Edwards,1997). When a factory is producing at a reduced capacity, it means not always determine if factory's knowledge workers are working at capacity. The competitive advantage of intellectual capital is enormous. This asset cannot be traded or expropriated. Competitors fall farther behind because the top talent goes to organisations such as Microsoft to be part of a leading-edge organisation.

\section{Findings}

This study finds out some benefits and problems, these are:

- It checks the corporate plan of the organisation. The corporate plan aiming for expansion, diversification, changes in technological growth etc. has to be worked out with the availability of human resources for such placements or key positions. If such manpower is not likely to be available, HR accounting suggests modification of the entire corporate plan.

- It offsets uncertainty and change, as it enables the organisation to have the right person for the right job at the right time and place.

- It provides scope for advancement and development of employees by effective training and development.

- It helps individual employee to aspire for promotion and better benefits.

- It aims to see that the human involvement in the organisation is not wasted and brings high returns to the organisation.

- It helps to take steps to improve employee contribution in the form of increased productivity. It provides different methods of testing to be used, interview techniques to be adopted in the selection process based on the level of skill, qualifications and experience of future human resources.

- It can foresee the change in value, aptitude and attitude of human resources and accordingly change the techniques of interpersonal management.

- The measure is an objective one because it uses widely based statistics such as census income return and mortality tables.

- Calculation process is lengthy and cumbersome. The soundness of the valuation depends wholly on the information, judgment, and impartiality of the bidder. 


\section{Conclusion}

Human Resource Accounting is the process of identifying and measuring data about human resources and communicating this information to interested parties. It provides a sound and effective basis of human asset control, that is, whether the asset is appreciated, depleted or conserved. The human asset accounting method attempts to use accounting principles, such as those used to calculate the historical costs or replacement costs of assets, to put a value on the worth of an organisation's human assets, present value of future earnings methods. The methods used in measuring the investment made in employees, treating them as capitalized resources, in economic terms. It has some advantages and limitations, now-a-days Human Resource Accounting is most thinkable term in Human Resource Management. It helps in the Strategic Human Resource Planning. It helps the organisation in decision making in the following areas: Direct Recruitment vs. promotion, transfer vs. retention, retrenchment vs. retention, impact on budgetary controls of human relations and organisational behaviour, decision on reallocation of plants closing down existing units and developing overseas subsidiaries etc.

\section{References}

[1]. Cascio,WF. Costing Human Resources: The Financial Impact of Behavior in Organisations, $3^{\text {rd }}$ ed. Kent Series in Human Resource Management. Boston; PWS Kent,1991.

[2]. Edwards,S "The Brain Gain”CA Magazine,April, p21-25,1997.

[3]. Flamholtz,FLK,D.G. Searfoss, and R.C "Developing Human Resource Accounting as a Decision Support System" Accounting Horizon, Vol.2,p1-9,1988.

[4]. Lermusiaux, Y "Managing Human Capital in a Downturn” Business Journal, Vol 66 No.- 4, March-April,p14-16,2002.

[5]. Lev,B and A.Schwartz "On the Use of the Economic Concept of Human Capital in Financial Statements" Accounting Review, Vol46 p103-112,1971.

[6]. Quinn,JB,P.Anderson, and S.Finkelstein "Leveraging Intellect" Academyof Management Executive, Vol.-10, No.-3,1966.

[7]. Scarpello,V. and H.A Theeke " Human Resource Accounting: A Measured Critique." Journal of Accounting Literature, Vol. $8, \mathrm{p} 265-280,1989$.

[8]. Steffy,B.D., and S.D. Maurer "Conceptualizing and Measuring the Economic Effectiveness of Human Resource Activities." Academy of Management Review, Vol. 13,p265-280,1988.

[9]. Stewart, T.A “Intellectual Capital” Fortune,3 October, p-68-74,1994.

[10]. hpt//www.hraccounting. 